\title{
Patients and Methods of the PATH Biobank - A Resource for Breast Cancer Research
}

\author{
Patientinnen und Methoden der PATH-Biobank - \\ Eine Ressource für die Brustkrebsforschung
}

Authors

Affiliations
A. Waldmann ${ }^{1}$, T. Anzeneder ${ }^{2}$, A. Katalinic ${ }^{1,3}$

${ }^{1}$ Institut für Sozialmedizin und Epidemiologie, Lübeck

2 Stiftung PATH, Augsburg

${ }^{3}$ Institut für Krebsepidemiologie e. V., Lübeck

\section{Key words \\ - breast \\ - epidemiology \\ - breast cancer \\ Schlüsselwörter \\ - Mamma \\ - Epidemiologie \\ - Mammakarzinom}

Deutschsprachige Zusatzinformationen online abrufbar unter: www.thieme-connect.de/ ejournals/toc/gebfra

\section{received $\quad 12.7 .2013$ \\ revised 21.10.2013 \\ accepted 19.11.2013}

\section{Bibliography}

DOI http://dx.doi.org/ 10.1055/s-0033-1360263

Geburtsh Frauenheilk 2014; 74:

361-369 @ Georg Thieme

Verlag KG Stuttgart · New York ISSN 0016-5751

\section{Correspondence}

\section{Dr. Annika Waldmann}

Institut für Sozialmedizin und Epidemiologie

Ratzeberger Allee (Haus 50)

23562 Lübeck

annika.waldmann@uksh.de

\section{Abstract \\ $\nabla$}

Introduction: The foundation PATH (Patients' Tumour Bank of Hope) collects in a tumour bank samples of blood, tumour, and tumour-near normal tissue from breast cancer patients and supplements them systematically with health-care data.

Material and Methods: For patients from the diagnosis years 2006-2009 quantitative data were evaluated with the help of mean values and standard deviations while for qualitative data absolute and relative incidences were assessed. Demographic and clinical features of women who used different numbers of information sources were tested for statistical significance by means of ANOVA and $X^{2}$ tests. The benchmark report of the WBC and two DMP reports were used to compare oncological care.

Results: For research purposes tumour tissue samples are available for $59 \%$ of the cases, normal tissue for $62 \%$ and blood serum samples for $92 \%$. From 3573 women (diagnoses 2006-2009), a total of 2697 women $(75.5 \%)$ took part in followup. The characteristics of the follow-up patients did not relevantly differ from those of all the patients. The responsible physician was named as the most important source of information about the disease. Young women in particular consulted several sources and also used the internet to obtain information.

Discussion: Compared with data on therapy from WBC and the DMP breast cancer in Bavaria or, respectively, North Rhineland reports, the PATH patients represent an only slightly selected sample. The PATH biobank is a (still) poorly used data and sample source, which is made available upon request and positive evaluation of the study protocol. Thus, it is possible to address current questions in a short time without having to undertake extensive recruiting procedures.

\section{Zusammenfassung \\ $\nabla$}

Einleitung: Die Stiftung PATH (Patients' Tumor Bank of Hope) sammelt in einer Biobank Blut, Tumor- und tumornahes Normalgewebe von Brustkrebspatienten und reichert diese systematisch mit Versorgungsdaten an.

Material und Methodik: Für Patientinnen aus den Diagnosejahren 2006-2009 wurden quantitative Daten mittels Mittelwerten und Standardabweichungen, qualitative Daten mit absoluten und relativen Häufigkeiten ausgewertet. Demografische und klinische Merkmale von Frauen, die unterschiedliche Anzahlen von Informationsquellen nutzen, wurden mittels ANOVA und $\mathrm{X}^{2}$ Test auf statistische Signifikanz getestet. Der Benchmarkbericht des WBC und 2 DMP-Berichte werden zum Vergleich der onkologischen Versorgung genutzt.

Ergebnisse: Zu Forschungszwecken liegen Tumorgewebeproben in 59\%, Normalgewebe in $62 \%$ und Blutserumproben in $92 \%$ der Fälle bereit. Von 3573 Frauen (Diagnose 2006-2009) wurden 2697 Frauen (75,5\%) nachbefragt. Die Charakteristika der Follow-up-Patientinnen unterscheiden sich nicht relevant von allen Patientinnen. Die Ärztin bzw. der Arzt wird als wichtigste Quelle für Informationen zur Erkrankung genannt. Insbesondere junge Frauen nutzen mehrere Quellen und ziehen auch das Internet zur Informationsbeschaffung heran.

Diskussion: Verglichen mit Daten zur Therapie aus dem WBC und dem DMP Brustkrebs in Bayern bzw. Nordrhein sind die PATH-Patientinnen eine wenig selektierte Stichprobe. Die PATH-Biobank ist eine (noch) wenig genutzte Daten- und Probenquelle, die auf Anfrage und Begutachtung des Studienprotokolls zur Verfügung gestellt wird. Somit bietet sich die Möglichkeit, aktuelle Fragestellungen ohne aufwendige Rekrutierungsmaßnahmen zeitnah zu bearbeiten. 


\begin{tabular}{|c|c|c|c|}
\hline \multicolumn{3}{|c|}{ PATH biobank } & \multirow[t]{3}{*}{ Fig. 1 Structure of the PATH biobank. } \\
\hline PATH tumour bank & $\begin{array}{r}\text { PATH } \\
\text { Central databa }\end{array}$ & $\begin{array}{l}\text { enbank } \\
\text { office in Munich }\end{array}$ & \\
\hline $\begin{array}{l}\text { Locations at the participat- } \\
\text { ing breast cancer centres } \\
\text { Fresh frozen }-155^{\circ} \mathrm{C} \\
\text { Serum samples } \\
\text { Tumour tissue } \\
\text { Tumour-near normal } \\
\text { tissue }\end{array}$ & $\begin{array}{l}\text { Basic data provided } \\
\text { by clinics, pathology, } \\
\text { discharge documents } \\
\text { Sociodemographic, } \\
\text { clinical and tumour } \\
\text { biological data } \\
\text { Surgical procedures } \\
\text { Recommended therapies }\end{array}$ & $\begin{array}{l}\text { Follow-up data provided } \\
\text { by the patients: } \\
\text { Further therapeutic } \\
\text { measures undertaken } \\
\text { Disease course } \\
\text { In future: } \\
\text { When required possible } \\
\text { contact with physician }\end{array}$ & \\
\hline
\end{tabular}

Fig. 1 Structure of the PATH biobank.

\section{Introduction \\ $\nabla$}

Breast cancer with around 78500 new cases per year (72000 invasive and 6500 in-situ tumours) is the most frequent cancer disease in women. In comparison with the early 1980s (ca. 55000 invasive cases), the incidence has increased by a factor of 1.5 . Over time in contrast, there has been a slight but continuous decrease in the mortality of breast cancer. Currently about 17200 women die of breast cancer each year in Germany [1].

The discrepancy between the increasing numbers of new cases and the decline in mortality can be attributed to advances in diagnostics and therapy. By means of optimised procedures in imaging techniques it is now possible to detect about $70 \%$ of all invasive cases in the prognostically favourable $\mathrm{T} 1$ or $\mathrm{T} 2$ stages [1]. Among the advances in therapy are, among others, the development of new therapeutic procedures such as sentinel lymph node removal or also chemotherapeutic agents, antihormonal therapy as well as further targeted substances and the introduction of disease management programmes and certified breast centres that have contributed to a better, more gentle care and an increased survival rate [1-4]. Even so, there is still a need for much more research and urgent action in the field of breast cancer, for example, in the particular subgroups such as young women or men with breast cancer, the optimal treatment and prognosis of triple-negative breast cancer, clarification of metastatic pathways and mechanisms, research on therapy resistance, or the use of bisphosphonates in the adjuvant situation. In the past decades and not only in Germany, biobanks - defined as "organised collections of human biological materials and associated data collections for research purposes" - have been implemented. The thus resulting availability of human material for basic research has made a large contribution to the identification of pathophysiological processes and biomarkers, especially in oncology. These markers can, in turn, not only give hints on the prognosis but also provide information about which localisation in the organism an individualised and targeted therapy may be applied [5,6]. In 2002 the PATH foundation (Patients' Tumour Bank of Hope) was created. The objective of the foundation is to collect and safely store samples of blood serum, tumour tissue and normal tissue surrounding tumours (tumour-near tissue) of breast cancer patients, to systematically supplement them with patient data and to make them available for research. Since 2004 more than 5900 women and men have made use of this possibil- ity. The collected data and samples can be made available upon request after evaluation and approval of a detailed study protocol. To date, eight research projects on the basis of PATH have been started (see also www.stiftungPATH.org) and in part already published [7-9]. The PATH biobank is introduced in the present paper. In addition, a description is given of the women included since 2006 and a comparison is made with other breast cancer collectives described in the literature.

\section{Material and Methods}

$\nabla$

\section{PATH biobank}

PATH was created in 2002 as a foundation with the objective of building up a biobank for breast cancer. The biobank consists of a central database (located in the PATH foundation) and decentrally organised tumour banks (located in the breast centres; - Fig. 1). A written individual consent for collection of the samples, for provision of the data for research purposes, for later questioning and the pseudonymised data processing are obligatory. This procedure was set up in consultation with the Bavarian data protection agency and positively assessed by the ethics committee of Bonn University. The first samples were taken up in a biobank at one location in 2004. After technical adjustments and revision of the standard operating procedures (SOP) a further location was added in 2005. Further cooperation partners were gained in the subsequent years. At present seven breast centres located in Dortmund, Cologne/Bonn, Herne/Bochum, Kassel, Marburg, Offenbach and Regensburg are cooperating with PATH. In the respective centres and after informed consent, patients can have blood samples, tumour tissue and normal tissue surrounding the tumour stored in nitrogen tanks (at minus $155^{\circ} \mathrm{C}$, gas phase storage, fresh frozen), the respective first samples are stored for the patient him/herself (patient sample tumour) and the remaining samples are made available for research purposes (research sample tumour). After the patient's death, the patient sample becomes the property of PATH and is thus also available for research purposes. With the exception of property rights, there are no differences between the patient samples and the research samples. The processing, handling and labelling of the samples are subject to strict standard operating procedures (SOP) that must be followed by the centres and are checked by a monitoring system. For the serum samples a minimum volume of 
$1 \mathrm{~mL}$ and for the tissue samples a minimum edge length of $3 \mathrm{~mm}$ are required. In addition to these samples, the breast centres hold physician and pathology reports from which the relevant information on the breast cancer disease, diagnosis and therapy recommendations can be extracted ( Fig. 1). Data extraction is undertaken by trained, medically-supervised personnel of the database office who are subject to the professional obligation of confidentiality. In cases of ambiguity the breast centre or responsible physician is contacted and asked for clarification. All clinical, tumour biological and patient-related follow-up information is stored in the central database (located in Munich) in pseudonymised form.

From the beginning of 2008 a concept was established and agreed upon for follow-up of the women. Thus, for the first time in March 2009 women who were diagnosed in the years from 2004 to 2007 could be contacted by letter in order to obtain follow-up data. The stored cases were processed in chronological order starting with the oldest. Up to the middle of 2010 all women including those with diagnosis and storage time points up to the middle of 2008 had been contacted. From this point onwards contact was made 24 months after the diagnosis.

In the follow-up survey, the importance of the renewed questioning was explained and a telephone interview was announced. In addition, the women were asked to name and release their responsible physician from his/her pledge of secrecy so that further information could be obtained if necessary. The telephone interview was conducted by trained personnel on the basis of a standardised interview guideline. The questions covered disease course as well as compliance with therapy and current health status. If the patients could not be reached by telephone they received a questionnaire containing the above-mentioned questions.

If the patient reported the occurrence of a follow-up event (recurrence or metastases or, respectively, gave unclear or incomplete information) the responsible physician could be contacted and requested to confirm or clarify the details.

\section{Patient selection}

Female patients of the diagnosis years 2006-2009 were taken into consideration. The years 2004 and 2005 were not taken into account due to the limited numbers included in the initial phases of building up the biobank. For the years 2010 to 2012 data collection and evaluation were not completed at the time point of the present evaluation (databank closing date June 2012), so that these patients were also excluded.

If the patient develops a metachronous tumour in the same breast or if there is bilateral disease, each time a "new" case is entered in the database. For the present evaluation in cases of metachronous breast cancers, the "primary cases" that resulted in deposition of the first tissue sample were considered. Women with bilateral disease are included in the evaluation as one case each for the affected breasts.

\section{Statistical analyses}

The description involves the entire collective and all women with follow-up data. Quantitative data are presented with mean values and standard deviations, qualitative data with absolute and relative frequencies. Self-reported therapy procedures were compared with data from the bench marking report of the West German Breast Centre (WBC) of 2009 [10] and two DMP quality assurance reports $[11,12]$. The information on therapy frequencies is reported with $95 \%$ confidence limits according to Altman [13].
Statistical differences with regard to sociodemographic and clinical features between women who use differing numbers of information sources were tested by means of ANOVA and the $\mathrm{X}^{2}$ test.

\section{Results \\ $\nabla$}

\section{Patient collective}

For the diagnosis period 2006-2009, 4071 patients were entered into PATH. Two centres each entered $11 \%$ of the patients in the collective, the other centres recruited respectively $4,15,16,19$ and $23 \%$ of the patients. Of these, 3573 women have already been contacted in the course of the follow-up (enrolment in the PATH database since at least 2 years). The mean difference between diagnosis date and time of the follow-up contact amounted to 27.3 (SD: 4.9) months. Merely 368 women had refused a follow-up observation at the time of acceptance in the biobank. In the period between entry in PATH and the time point of follow-up 143 women had died (31 with breast cancer as cause of death, 106 with unclarified causes of death). At the follow-up interview 48 reported a locoregional recurrence and 114 women metastases. Altogether 2697 women (2697/3573 =75.5\%; 2697/[3573$143]=78.6 \%$ ) were available for the follow-up interview. There were no recorded personal or clinically relevant differences between the subgroup of patients with follow-up and all accepted women in the collective. Thus, the average age at disease onset in both groups was about 60 years and about $7 \%$ revealed breast cancer disease in their personal case histories. About $93 \%$ of the women had a tumour in tumour stage T1 or T2 and only $3.6 \%$ exhibited distant metastases. $81 \%$ were oestrogen receptor-positive, $71 \%$ were progesterone receptor-positive and about $13 \%$ of the women were Her2/neu receptor-positive ( $\bullet$ Table 1 ).

\section{Oncological management}

About $78 \%$ of all PATH patients reported a breast-conserving therapy. If only women with T1 tumours are considered this value increases to $86.5 \% .90 .4 \%$ of the PATH patients reported on a subsequent radiotherapy after breast-preserving treatment. Chemotherapy in cases with affected lymph nodes and negative hormone receptor status was reported by $70.9 \%$ of the PATH patients. Bisphosphonate therapy was mentioned by merely $17 \%$ (- Table 2).

\section{Information sources}

In the course of the follow-up questions were posed about sources of information about breast cancer (exact wording: "How and where do you obtain information about breast cancer?" "Which media or sources do you use to get information about your own disease?"). 1887 patients gave a valid answer to this (these) question(s) and altogether named 4414 sources (average value 2.2 information sources per woman, standard deviation: 1.2 ). $58.1 \%$ of the interviewed women mentioned one or two sources, further $26.9 \%$ used three sources of information and the remaining $15.0 \%$ consulted four or more sources of information. As a general rule the younger the patient the more were the information sources she used ( $p<0.001$, ANOVA) and the more had the tumour spread to the lymph nodes $\left(p=0.013, X^{2}\right)$, on the other hand, the type of operation or the presence of distant metastases had no influence on the number of information sources used. The most frequently mentioned source of information was the treating physician (38.1\% of all nominations, by $89.2 \%$ of all 
Table 1 Clinical and anamnestic data of all PATH patients and those with follow-up.

\begin{tabular}{|c|c|c|}
\hline & $\begin{array}{l}\text { All patients } \\
(n=4071)\end{array}$ & $\begin{array}{l}\text { Follow-up-pa- } \\
\text { tients }(n=2697)\end{array}$ \\
\hline \multicolumn{3}{|l|}{ Age at diagnosis } \\
\hline mean $\pm S D$ & $59.8 \pm 12.1$ & $60.1 \pm 11.5$ \\
\hline \multicolumn{3}{|l|}{ Age groups } \\
\hline$><40$ & $199(4.9)$ & $98(3.6)$ \\
\hline > $40-74$ & $3426(84.2)$ & $2333(86.5)$ \\
\hline$\geq 75$ years & $446(11.0)$ & $266(9.9)$ \\
\hline \multicolumn{3}{|c|}{ Personal anamnesis (previous breast cancer) } \\
\hline yes & $303(7.4)$ & $199(7.4)$ \\
\hline$\checkmark$ no & $3745(92.0)$ & $2483(92.1)$ \\
\hline not known & $23(0.5)$ & $15(0.5)$ \\
\hline \multicolumn{3}{|l|}{ Menopausal status } \\
\hline - premenopausal & $653(16.0)$ & $404(15.0)$ \\
\hline perimenopausal & $90(2.2)$ & $52(1.9)$ \\
\hline postmenopausal* & $2818(69.2)$ & $1926(71.4)$ \\
\hline not known & $510(12.5)$ & $315(11.7)$ \\
\hline \multicolumn{3}{|l|}{ TNM-T** } \\
\hline$>\mathrm{T} 1$ & $2224(63.5)$ & $1549(65.4)$ \\
\hline > $\mathrm{T} 2$ & $1085(31.0)$ & $713(30.1)$ \\
\hline$>\mathrm{T} 3$ & $112(3.2)$ & $67(2.8)$ \\
\hline$>\mathrm{T} 4$ & $57(1.6)$ & $25(1.1)$ \\
\hline$>\mathrm{Tx}$ & $24(0.7)$ & $15(0.6)$ \\
\hline \multicolumn{3}{|l|}{ TNM-N** } \\
\hline$>\mathrm{NO}$ & $2284(65.2)$ & $1586(66.9)$ \\
\hline D 1 & $797(22.8)$ & $530(22.4)$ \\
\hline - N2 & $217(6.2)$ & $135(5.7)$ \\
\hline$\checkmark \mathrm{N3}$ & $131(3.7)$ & $75(3.2)$ \\
\hline$>\mathrm{Nx}$ & $73(2.1)$ & $43(1.8)$ \\
\hline \multicolumn{3}{|l|}{ TNM-M** } \\
\hline$\rightarrow \mathrm{M} 0$ & $3206(91.5)$ & $2199(92.8)$ \\
\hline > M1 & $103(2.9)$ & $46(1.9)$ \\
\hline - Mx & $193(5.5)$ & $124(5.2)$ \\
\hline \multicolumn{3}{|l|}{ Resection margins** } \\
\hline > R0 & $3396(97.0)$ & $2310(97.5)$ \\
\hline > R1 & $47(1.3)$ & $24(1.0)$ \\
\hline - R2 & $4(0.1)$ & $2(0.1)$ \\
\hline D $\mathrm{Rx}$ & $55(1.6)$ & $33(1.4)$ \\
\hline \multicolumn{3}{|c|}{ Number of affected lymph nodes** } \\
\hline - mean $\pm \mathrm{SD}$ (min. - max.) & $1.34 \pm 3.72(0-59)$ & $1.13 \pm 3.06(0-36)$ \\
\hline \multicolumn{3}{|c|}{ Number of removed lymph nodes ** } \\
\hline - mean $\pm \mathrm{SD}($ min. - max. $)$ & $7.60 \pm 7.45(0-61)$ & $7.35 \pm 7.18(0-58)$ \\
\hline \multicolumn{3}{|l|}{ Oestrogen receptor status } \\
\hline positive & $3275(80.4)$ & $2209(81.9)$ \\
\hline negative & $753(18.5)$ & $457(16.9)$ \\
\hline not known & $43(1.1)$ & $31(1.1)$ \\
\hline \multicolumn{3}{|l|}{ Progesterone receptor status } \\
\hline positive & $2684(70.4)$ & $1943(72.0)$ \\
\hline negative & $1163(28.6)$ & $723(26.8)$ \\
\hline not known & $44(1.1)$ & $31(1.1)$ \\
\hline \multicolumn{3}{|l|}{ Her2/neu status*** } \\
\hline positive & $524(12.9)$ & $331(12.3)$ \\
\hline negative & $3488(85.7)$ & $2326(86.2)$ \\
\hline not known & $59(1.4)$ & $40(1.5)$ \\
\hline \multicolumn{3}{|l|}{ Triple negative } \\
\hline yes & $465(11.4)$ & $281(10.4)$ \\
\hline no & $3540(87.0)$ & $2369(87.8)$ \\
\hline not known & $66(1.6)$ & $47(1.7)$ \\
\hline
\end{tabular}

* Given in physicians letter or patient aged over 60 years. ${ }^{* *}$ Selection: primary breast cancer and adjuvant therapy; $\mathrm{n}$ total $=3502$ or, respectively. $\mathrm{n}$ follow-up $=2369$.

*** Definition Her2/neu positivity: result of FISH/SISH/CISH test. If this is not available, the result of an IHC test is taken into account: $3+$ is assessed as positive, $0-2+$ is considered as negative - unless the patients in the case of $\mathrm{IHC2}+$ received a recommendation for herceptin therapy in the breast centre, the Her2/neu status is then considered to be positive. patients) followed by information pamphlets ( 21.4 or, respectively, 50.0\%; @ Table 3).

\section{Serum and tissue samples}

Blood serum samples for the patients or, respectively, for research purposes are available for 95 or, respectively, $92 \%$ of the women. Tumour tissue samples are held in trust for about $73 \%$ of the patients and tumour tissue samples for research purposes for about $59 \%$ of them ( $\boldsymbol{O}$ Fig. $\mathbf{2}$ ). In addition, samples of normal tissue surrounding the tumour obtained from OP specimens for $62 \%$ of the cases are available for research.

The majority of the patients suffered from strictly localised tumours ( $\bigcirc$ Table 1). $\bigcirc$ Fig. 3 illustrates the storage of tumour samples differentiated according to tumour stage. Whereas research samples of the higher tumour stages (T2/T3/T4) have been deposited for more than $87 \%$ of the cases, as a consequence of the amount of available tumour material this holds for the lower stages only in $18.8 \%$ (pT1a), $25.3 \%$ (pT1b) or, respectively, $64.1 \%$ (pT1c) of the cases.

\section{Discussion}

The PATH (Patients' Tumour Bank of Hope) foundation was formed in 2002. To date there is cooperation with seven hospitals that deposit samples from breast cancer patients in the PATH biobank after informed consent. The sample collection includes specimens of blood, tumour tissue, and normal tissue from the vicinity of the tumour. Clinical, anamnestic and therapeutic data are stored in the data base. About two years after diagnosis, information about compliance with the therapy, the disease course and survival is collected by an in part telephone and in part written interview.

\section{The PATH collective}

In Germany the average age of patients at diagnosis of breast cancer is about 65 years [1]. The PATH patients are on average about 5 years younger and thus rather more comparable with the women who had taken part in the two oncological health-care research studies performed in Germany (OVIS study: mean age at diagnosis: 59 years [14]; VERDI study: mean age at diagnosis: 57 years [15]). About $65 \%$ of the PATH patients were in tumour stage $\mathrm{T} 1$ and a further $30 \%$ in tumour stage $\mathrm{T} 2$. Thus, the tumour stage distribution is by far more favourable than that of all afflicted women in Germany [1] or, respectively, slightly more favourable than that of all women included in the OVIS study [14] and of the women of the WBC cooperating hospitals [10]. The proportion of women with distant metastases was only slightly higher than that of the VERDI study in Saarland (1.6\%) [15]. It could be shown that there was rather a tendency for younger women and those with more favourable tumour stages to be willing to participate in research projects and that such patients could be more frequently recruited for such trials [16-19]. This also appears to be true for the PATH biobank. When all women who have to date been enrolled in PATH are compared with those with completed follow-up interviews, no further selection process can be observed. The response rate achieved here of $76 \%$ (or, respectively, $79 \%$ ) in the follow-up interview is somewhat lower than those of other oncological health-care research studies [15,20-22], but can be considered as sufficient against the background of the similarities between all patients and those with completed follow-ups. 
Table 2 Therapy data of the PATH patients with follow-up as well as indicators from the WBC bench mark report 2009 and the DMP-reports of the years 2010 (North Rhineland) or, respectively, 2011 (Bavaria).

\begin{tabular}{|c|c|c|c|c|c|}
\hline & $\begin{array}{l}\text { PATH } \\
\text { absolute and } \\
\text { relative frequen- } \\
\text { cies }(n=2697)\end{array}$ & $\begin{array}{l}\text { PATH } \\
\text { relative frequency } \\
\text { referred to the } \\
\text { valid answers } \\
\text { (yes/no) ( } 95 \% \mathrm{Cl} \text { ) }\end{array}$ & $\begin{array}{l}\text { Bench mark } \\
\text { report WBC } \\
\text { number } \\
\text { relative frequency } \\
(95 \% \mathrm{Cl})[10]\end{array}$ & $\begin{array}{l}\text { Quality report } \\
\text { DMP breast } \\
\text { cancer Bavaria } \\
\text { number } \\
\text { relative frequency } \\
(95 \% \mathrm{Cl})[11]\end{array}$ & $\begin{array}{l}\text { Quality report } \\
\text { DMP breast } \\
\text { cancer North } \\
\text { Rhineland } \\
\text { number } \\
\text { relative frequency } \\
(95 \% \mathrm{Cl}) \text { [12] }\end{array}$ \\
\hline Breast preserving therapy (BPT) & & $\mathrm{n}=2684$ & $\mathrm{n}=36369$ & & \\
\hline > yes & $2096(77.7)$ & $78.1(76.5 ; 79.7)$ & $72.0(71.5 ; 72.5)$ & - & - \\
\hline no & $588(21.8)$ & & & & \\
\hline not known & $13(0.5)$ & & & & \\
\hline T1 tumour and BPT & & $n=1723$ & $\mathrm{n}=17772$ & $\mathrm{n}=3896$ & $\mathrm{n}=7496$ \\
\hline yes & $1491(68.3)$ & $86.5(84.9 ; 88.1)$ & $85.0(84.5 ; 85.5)$ & $88.0(67.0 ; 89.0)$ & $82.2(81.3 ; 83.1)$ \\
\hline no & $232(13.4)$ & & & & \\
\hline not known & $4(0.2)$ & & & & \\
\hline $\mathrm{T} 1 / \mathrm{T} 2$ tumour and BPT & & $\mathrm{n}=2504$ & & & \\
\hline yes & $2031(80.8)$ & $81.1(79.6 ; 82.6)$ & - & - & - \\
\hline$>$ no & $473(18.8)$ & & & & \\
\hline - not known & $9(0.4)$ & & & & \\
\hline Radiotherapy & & $n=2473$ & & & \\
\hline$\checkmark$ yes & $2194(81.3)$ & $88.7(87.5 ; 89.9)$ & - & - & - \\
\hline no & $279(10.3)$ & & & & \\
\hline not known & $224(8.3)$ & & & & \\
\hline Radiotherapy after BPT & & $n=1955$ & $n=21212$ & $\mathrm{n}=1070$ & $n=8967$ \\
\hline D yes & $1894(90.4)$ & $90.4(89.1 ; 91.7)$ & $85.0(84.5 ; 85.5)$ & $85.0(82.9 ; 87.1)$ & $62.0(61.0 ; 63.0)$ \\
\hline no & $61(2.9)$ & & & & \\
\hline not known & $141(6.7)$ & & & & \\
\hline Chemotherapy & & $n=2252$ & & & \\
\hline$\checkmark$ yes & $1160(43.0)$ & $51.5(49.4,53.6)$ & - & - & - \\
\hline no & $1092(40.5)$ & & & & \\
\hline not known & $445(16.5)$ & & & & \\
\hline $\begin{array}{l}\text { Chemotherapy in cases of positive } \\
\text { nodes and negative hormone } \\
\text { receptors }\end{array}$ & & $n=101$ & $n=6800$ & $\mathrm{n}=198$ & $n=684$ \\
\hline yes & $95(70.9)$ & $70.9(62.0 ; 79.8)$ & $75.0(74.0 ; 76.0)$ & $78.0(72.2 ; 83.8)$ & $78.1(75.0 ; 81.2)$ \\
\hline no & $6(4.5)$ & & & & \\
\hline not known & $33(24.6)$ & & & & \\
\hline Antihormonal therapy & & $n=2427$ & & & \\
\hline - yes & $2042(75.7)$ & $75.7(74.0 ; 77.4)$ & - & - & - \\
\hline no & $385(14.5)$ & & & & \\
\hline not known & $270(10.0)$ & & & & \\
\hline $\begin{array}{l}\text { Antihormonal therapy with positive } \\
\text { hormone receptors }\end{array}$ & & $n=2054$ & $n=27956$ & $n=916$ & $n=10328$ \\
\hline yes & $1984(87.5)$ & $87.5(86.1 ; 88.9)$ & $97.0(96.8 ; 97.2)$ & $91.0(89.2 ; 92.9)$ & $69.9(69.0 ; 70.8)$ \\
\hline no & $70(3.1)$ & & & & \\
\hline not known & $213(9.4)$ & & & & \\
\hline Herceptin & & $n=2431$ & & & \\
\hline$\checkmark$ yes & $254(9.5)$ & $9.4(8.2 ; 10.6)$ & - & & \\
\hline no & $2177(80.7)$ & & & & \\
\hline not known & $266(9.9)$ & & & & \\
\hline Herceptin with positive Her2-neu & & $\mathrm{n}=300$ & & & \\
\hline - yes & $225(68.0)$ & $68.0(62.7 ; 73.3)$ & - & & \\
\hline no & $75(22.7)$ & & & & \\
\hline not known & $31(9.4)$ & & & & \\
\hline Bisphosphonate therapy & & $n=2432$ & & $\mathrm{n}=164$ & $\mathrm{n}=518$ \\
\hline yes & $414(15.4)$ & $17.0(15.5 ; 18.5)$ & - & $82.0(76.1 ; 87.9)$ & $88.8(86.1 ; 91.5)$ \\
\hline no & $2018(74.8)$ & & & & \\
\hline not known & $265(9.8)$ & & & & \\
\hline
\end{tabular}

Special features WBC: planning of hormone therapy evaluated, since the therapy is often carried out at some time after residence in the WBC cooperation clinic. Special features DMP breast cancer: North Rhineland and Bavaria: bisphosphonate therapy in cases with bone metastases. Only North Rhineland: Radiotherapy in cases of BPT already completed at the time of the report. 


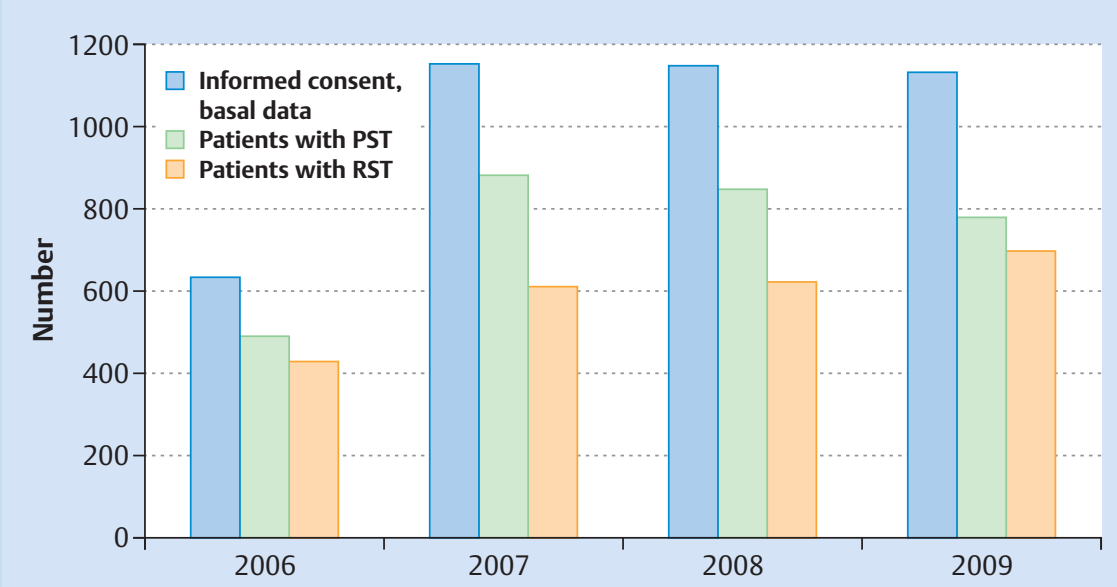

Fig. 2 Number of enrolled patients with informed consent and number of stored tissue samples.

PST: Patient sample tumour

RST: Research sample tumour

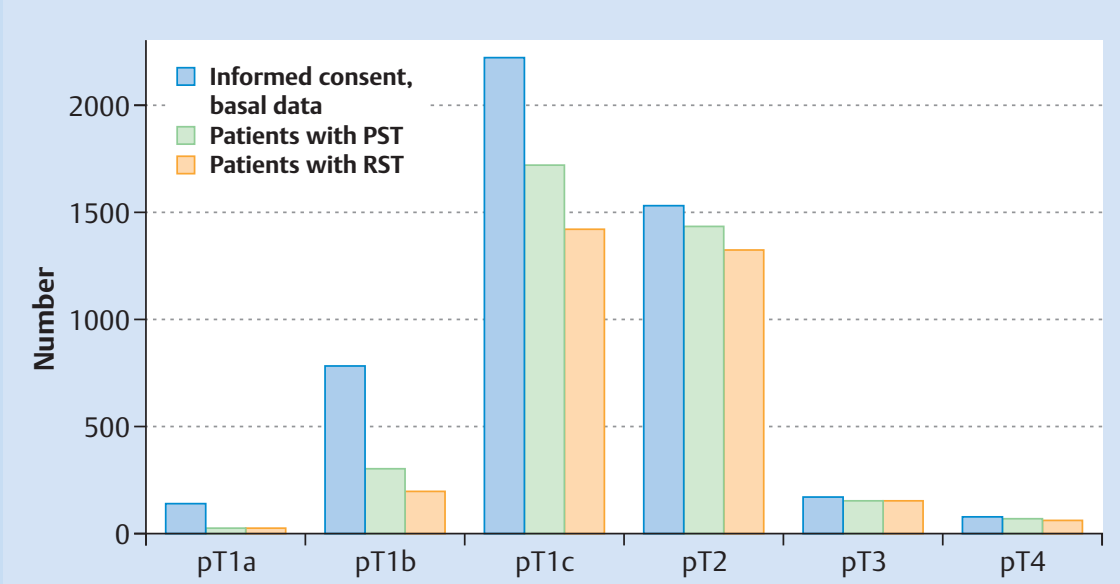

Fig. 3 Number of enrolled patients with informed consent and number of stored tissue samples according to tumour stage.

PST: Patient sample tumour

RST: Research sample tumour

Table 3 Which sources were used to obtain information about the disease (entire collective, differentiated according to number of sources used).

\begin{tabular}{|c|c|c|c|c|c|c|c|c|}
\hline & \multicolumn{2}{|c|}{$\begin{array}{l}\text { Absolute and relative fre- } \\
\text { quencies of named informa- } \\
\text { tion sources ( } 1887 \text { women) }\end{array}$} & \multicolumn{2}{|c|}{$\begin{array}{l}\text { 1-2 sources used } \\
\text { (1 } 097 \text { women) }\end{array}$} & \multicolumn{2}{|c|}{$\begin{array}{l}3 \text { sources used } \\
\text { ( } 507 \text { women) }\end{array}$} & \multicolumn{2}{|c|}{$\begin{array}{l}\text { 4-6 sources used } \\
\text { ( } 283 \text { women) }\end{array}$} \\
\hline & $\begin{array}{l}\text { Frequency } \\
\text { of naming }\end{array}$ & $\begin{array}{l}\text { Percent } \\
\text { referred to } \\
\text { number } \\
\text { of patients }\end{array}$ & $\begin{array}{l}\text { Frequency } \\
\text { of naming }\end{array}$ & $\begin{array}{l}\text { Percent } \\
\text { referred to } \\
\text { number } \\
\text { of patients }\end{array}$ & $\begin{array}{l}\text { Frequency } \\
\text { of naming }\end{array}$ & $\begin{array}{l}\text { Percent } \\
\text { referred to } \\
\text { number } \\
\text { of patients }\end{array}$ & $\begin{array}{l}\text { Frequency } \\
\text { of naming }\end{array}$ & $\begin{array}{l}\text { Percent } \\
\text { referred to } \\
\text { number } \\
\text { of patients }\end{array}$ \\
\hline Physician & 1683 & 89.2 & 947 & 86.3 & 461 & 90.9 & 275 & 97.2 \\
\hline Pamphlets & 943 & 50.0 & 259 & 23.6 & 406 & 80.1 & 278 & 98.2 \\
\hline Journals & 676 & 35.8 & 179 & 16.3 & 273 & 53.8 & 224 & 79.2 \\
\hline Internet & 584 & 30.9 & 153 & 13.9 & 209 & 41.2 & 222 & 78.4 \\
\hline Patient events & 401 & 21.3 & 108 & 9.8 & 132 & 26.0 & 161 & 56.9 \\
\hline Other sources & 127 & 6.7 & 30 & 2.7 & 40 & 7.9 & 57 & 20.1 \\
\hline
\end{tabular}


At the time point of the follow-up (on average 27.7 months after diagnosis) $4 \%$ of the breast cancer patients had already died. This corresponds approximately to the proportion of women of the Verdi study who had died after one year [23]. This improved survival is probably due to the comparatively more favourable tumour stages of the PATH patients.

\section{Reliability of patient information regarding oncological care}

As a result of the decentralised organisation of the health-care services, data from the individual care providers (such as therapy and rehabilitation) are deposited in various databases in Germany. A synopsis of these data is thus not possible due to the lack of uniform personal identification numbers. Patient questionnaires can be considered as one option for a comprehensive description of the health-care situation. However, even today the question as to whether patients are able to describe their (oncological) health care in a valid and reliable manner is a subject of controversy. Various investigations on the test-retest reliability of questionnaires have revealed a good to moderate reliability whereby the second questioning was carried out a few months to one year after the first one [24-30]. Also the validity of patient information concerning diagnostics, therapy and rehabilitation has been demonstrated in various trials [31-36].

\section{Oncological management of the PATH patients}

For the comparison of the oncological management, we used the WBC bench mark report [10] as well as the quality assurance reports of the DMP breast cancer in Bavaria [11] or, respectively, North Rhineland [12]. These reports were chosen on the basis of the regional agreement with the seven PATH cooperation hospitals. When the data for therapy frequency of the PATH patients did not markedly differ from data in the reports it can be assumed that the PATH patients were recruited with only little or no selection. The age distribution of the PATH women $(54 \% \geq 60$ years) is similar to that of the WBC patients ( $58 \% \geq 60$ years). Also the proportion of PATH women with T1 tumours who had undergone breast-preserving therapy was similar to that of the WBC collective. However, the proportion of women with subsequent radiotherapy after breast-conserving therapy in the PATH collective was five percent higher than those in the WBC bench mark report and in DMP breast cancer Bavaria (85\% each) and markedly higher than that in DMP breast cancer North Rhineland (62\%). This is possibly attributable to the time point of data registration. Thus the PATH women were interviewed about therapy at a minimum period of two years after diagnosis whereas in the bench mark report or, respectively, in the DMP reports, data were recorded at a shorter time after diagnosis and the documentation did not take a planned or a not completed radiotherapy into consideration for the calculations. This situation is especially apparent in the data from North Rhineland.

In contrast, chemotherapy for cases with lymph node involvement and negative hormone receptor status was less frequently reported by the PATH collective (71\%) than by the comparison collectives (75-78\%). Whether or not this is due to patient wishes or different therapeutic behaviour of the treating physicians cannot be determined on the basis of the available data.

Of all interviewed PATH women, 17\% reported a bisphosphonate therapy. When only those women with metastases (in any location) were taken into consideration, the proportion with bisphosphonate therapy rose to $60.5 \%$. In the DMP quality assurance reports, mention of bisphosphonate therapy was referred to all women with bone metastases and thus with an incidence of $>80 \%$ was markedly higher than in the population of all patients.

\section{Sources of information}

The results of several trials clearly reveal that medical as well as non-medical personnel followed by print media or, respectively, books are the most important sources of information about the disease and its therapy [37-41]. While older women rather rely on their physician as (sole) source of information, younger women tend to consult several sources for information about their disease [37]. Both of these situations also hold for the PATH patients. The importance of the internet as a source of information has been investigated in several studies with oncological patients. It was found that the significance of this source varied from about $10 \%$ to about $50 \%$ for all cancer patients who had searched for information about their disease and therapy in the internet $[39,40$, 42]. For the PATH patients it was found that especially the younger women searched for information in the internet. On average, the group of internet users is 10 years younger than those women who had not used the internet as an information source. Other studies have also come to the conclusion that especially the younger patients use the internet as information source [43-45].

\section{Previous use of PATH data for research projects}

The first samples were provided in 2008. Since then one group has evaluated the data [7] and eight further research groups have worked with PATH material and data. Not only tumour and normal tissue samples but also blood serum samples were used. The executive board of the PATH foundation after consultation with board of trustees and/or the scientific advisory committee decides about the provision of samples. Qualitative feedback about the properties of the various samples (for example, tumour content, RIN values, etc.) indicates a very high scientific utility of the samples. Also, correlations between the data available in the database with the results of investigations were easily possible. $\mathrm{Al}$ together, since the second half of 2011 there has been an increase in the number of applications for research materials. Because of the availability of a very large total collective and extensive descriptions of the collective with clinical and biological data, it is also possible to service special study protocols. The development and implementation of the PATH biobank has enabled studies with sufficiently large case numbers of homogeneous sample material to be undertaken. This view is substantiated by the various already successfully performed projects of the mostly early cancer research $[8,9]$. However, when using these samples it must be considered that there is a tendency that women with prognostically favourable tumour stages participate in PATH, but that within the group of lower tumour stages $(\mathrm{T} 1, \mathrm{~T} 2)$ the tissue samples available for research for originate rather from women with higher tumour stages (T1c, T2).

\section{Conclusions for Clinical Practice}

$\nabla$

The PATH research database with at present almost 6000 documented patients is an as yet little used source for descriptions of the health care of patients with breast cancer. Compared with the data from the West German Breast centre and the DMP breast cancer Bavaria or, respectively North Rhineland, the PATH patients represent a somewhat selected sample. The supplementary information and the deposited samples of serum, tumour tissue and tissue from the vicinity of the tumour can be made avail- 
able on request and after positive evaluation of the study proposal. Thus there is a potential opportunity to examine current problems without at first having to recruit patients.

\section{Acknowledgements}

We heartily thank all patients who were willing to deposit samples in PATH and to share their "disease histories". Without their support the research work would not be possible. In addition we thank the participating gynaecologists and pathologist in the cooperating centres in Bonn (PATH contact partner: Prof. Dr. UweJochen Göhring, Prof. Dr. Walter Kuhn), Dortmund (PD Dr. Georg Kunz), Bochum/Herne (Prof. Dr. Clemens Tempfer, Dr. H.Y. Ergönenc), Kassel (Prof. Dr. Thomas Dimpfl), Marburg (Prof. Dr. UteSusann Albert), Offenbach (Prof. Dr. Christian Jackisch) und Regensburg (Prof. Dr. Olaf Ortmann; see also http://www.stiftungpath.org/kooperationspartner/kooperationskliniken) for their engagement.

Without the financial support of private persons and companies, PATH could not have been established. They also deserve our thanks. Among the donors and sponsors are: Amgen, Munich, AstraZeneca, Wedel, Hans Anzeneder, Burghausen, Bristol-Myers Squibb, Munich, Prof. Reinhard Büttner, University of Bonn, Förderverein Robert Janker Krebsstiftung e.V., Bonn, GlaxoSmithKline, Munich, Henkel Stiftung, Düsseldorf, MammaMia, the Brustkrebsmagazin, Dr. Patrizia Mikulcik, Bad Homburg, Notaries Zimmermann and Hauschild, Düsseldorf, Novartis Pharma, Nuremberg, Pfizer Oncology, Berlin, Pierre Fabre, Freiburg, Revierinitiative Bochum Herne, Roche Pharma, Grenzach, Unterweger Healthcare Communication, Hamburg (see also http://stiftungpath.org/organisation/foerderer-sponsoren).

\section{Conflict of Interest}

The PATH foundation is financially supported by private persons and companies in its work to finance its establishment and the necessary logistics for deposition of tissue samples as well as for maintenance of the tumour bank (see above or, respectively, http://stiftungpath.org/organisation/foerderer-sponsoren).

There is no conflict of interest in the present article since these evaluations were carried out by external and independent agencies (Institute for Social Medicine and Epidemiology; Institute for Cancer Epidemiology). Furthermore, there was no financial or non-financial support regarding this evaluation by the private persons or companies that support PATH. The external evaluation agencies had no contact whatsoever with the supporting companies and private persons.

\section{References}

1 RKI, GEKID. Krebs in Deutschland 2007-2008. Häufigkeiten und Trends. 8. überarbeitete Auflage. Saarbrücken: Robert Koch-Institut und die Gesellschaft der epidemiologischen Krebsregister in Deutschland, Hrsg.; 2012

2 Brenner H, Stegmaier C, Ziegler H. Long-term survival of cancer patients in Germany achieved by the beginning of the third millenium. Ann Oncol 2005; 16: 981-986

3 De Angelis R, Tavilla A, Verdecchia A et al. Breast cancer survivors in the United States: geographic variability and time trends, 2005-2015. Cancer 2009; 115: 1954-1966

4 Warren JL, Mariotto AB, Meekins A et al. Current and future utilization of services from medical oncologists. J Clin Oncol 2008; 26: 3242-3247
5 Herpel E, Hummel M. [Research biobanks-development and structure]. Dtsch Med Wochenschr 2013; 138: 1069-1072

6 Hewitt RE. Biobanking: the foundation of personalized medicine. Curr Opin Oncol 2011; 23: 112-119

7 Fick E, Anzeneder T, Katalinic A et al. Bisphosphonates and their role in therapy for breast cancer - results from the PATH biobank [Bisphosphonate und ihre Rolle in der Therapie des Mammakarzinoms - Ergebnisse aus der Biobank PATH]. Geburtsh Frauenheilk 2013; 73: 412-421

8 Gevensleben H, Gohring UJ, Buttner R et al. Comparison of MammaPrint and TargetPrint results with clinical parameters in German patients with early stage breast cancer. Int J Mol Med 2010; 26: 837-843

9 Kloten V, Becker B, Winner $K$ et al. Promoter hypermethylation of the tumor-suppressor genes ITIH5, DKK3, and RASSF1A as novel biomarkers for blood-based breast cancer screening. Breast Cancer Res 2013; 15: R4

10 WBC Westdeutsches Brust-Centrum GmbH, Hrsg. Benchmarking WBC. Jahresbericht 2009. Bonn: Mediengestaltung Claus; 2010

11 Donnachie E, Hofmann F, Keller M et al., Hrsg. Qualitätsbericht 2010. Disease Management Programme in Bayern. München: 2011

12 Hagen B, Altenhofen L, Blaschy S et al., Hrsg. Qualitätssicherungsbericht 2009. Disease-Management-Programme in Nordrhein. Aufl. Köln-Weiden: Echo VERLAGSGRUPPE GmbH; 2010

13 Altman D, Machin D, Bryant TN et al. Statistics with confidence: confidence intervals and statistical guidelines. London: John Wiley \& Sons; 2003

14 Waldmann A, Pritzkuleit R, Raspe $H$ et al. Guideline-compatible treatment of breast cancer patients: the status quo in Schleswig-Holstein. Dtsch Arztebl Int 2008; 105: 337-343

15 Arndt V, Merx H, Sturmer T et al. Age-specific detriments to quality of life among breast cancer patients one year after diagnosis. Eur J Cancer 2004; 40: 673-680

16 Kemeny MM, Peterson BL, Kornblith $A B$ et al. Barriers to clinical trial participation by older women with breast cancer. J Clin Oncol 2003; 21: $2268-2275$

17 Lakerveld J, Ijzelenberg W, van Tulder MW et al. Motives for (not) participating in a lifestyle intervention trial. BMC Med Res Methodol 2008; 8: 17

18 Pritzkuleit $R$, Waldmann A, Raspe $H$ et al. The population-based oncological health care study OVIS - recruitment of the patients and analysis of the non-participants. BMC Cancer 2008; 8: 311

19 Simon MS, Du W, Flaherty L et al. Factors associated with breast cancer clinical trials participation and enrollment at a large academic medical center. J Clin Oncol 2004; 22: 2046-2052

20 Arndt V, Merx H, Stegmaier C et al. Quality of life in patients with colorectal cancer 1 year after diagnosis compared with the general population: a population-based study. J Clin Oncol 2004; 22: 4829-4836

21 Lehto US, Ojanen M, Kellokumpu-Lehtinen P. Predictors of quality of life in newly diagnosed melanoma and breast cancer patients. Ann Oncol 2005; 16: 805-816

22 Karakiewicz PI, Tanguay S, Kattan MW et al. Erectile and urinary dysfunction after radical prostatectomy for prostate cancer in Quebec: a population-based study of 2415 men. Eur Urol 2004; 46: 188-194

23 Arndt V, Stegmaier C, Ziegler $H$ et al. A population-based study of the impact of specific symptoms on quality of life in women with breast cancer 1 year after diagnosis. Cancer 2006; 107: 2496-2503

24 Adelstein B, Irwig L, Macaskill P et al. A self administered reliable questionnaire to assess lower bowel symptoms. BMC Gastroenterol 2008; 8: 8-17

25 Oberst $K$, Bradley $C J$, Schenk M. Breast and prostate cancer patient's reliability of treatment reporting. J Registry Manag 2009; 36: 12-15

26 Penfold RB, Kullgren JT, Miroshnik I et al. Reliability of a patient survey assessing cost-related changes in health care use among high deductible health plan enrollees. BMC Health Serv Res 2011; 11: 133

27 Radbruch L, Sabatowski R, Elsner F et al. Validation of the German version of the brief fatigue inventory. J Pain Symptom Manage 2003; 25: 449-458

28 Renzi C, Mastroeni S, Mannooranparampil TJ et al. Reliability of self-reported information on skin cancer among elderly patients with squamous cell carcinoma. Ann Epidemiol 2011; 21: 551-554

29 Slanger T, Mutschelknauss E, Kropp S et al. Test-retest reliability of selfreported reproductive and lifestyle data in the context of a German case-control study on breast cancer and postmenopausal hormone therapy. Ann Epidemiol 2007; 17: 993-998 
30 Waldmann A, Dreckschmidt J, Pritzkuleit R et al. Test-Retest Reliabilität des OVIS-Fragebogens - ein Instrument zur Evaluation der onkologischen Versorgung aus Patientensicht. [Test-retest reliability of the OVIS Questionnaire - an instrument to evaluate oncological care from a patient's point of view]. Gesundheitswesen 2010; 72: 707-713

31 Greenlaw SM, Yentzer BA, O'Neill JL et al. Assessing adherence to dermatology treatments: a review of self-report and electronic measures. Skin Res Technol 2010; 16: 253-258

32 Gupta V, Gu K, Chen Z et al. Concordance of self-reported and medical chart information on cancer diagnosis and treatment. BMC Med Res Methodol 2011; 11: 72

33 Jones JM, McPherson CJ, Zimmermann C et al. Assessing agreement between terminally ill cancer patients' reports of their quality of life and family caregiver and palliative care physician proxy ratings. J Pain Symptom Manage 2011; 42: 354-365

34 Ritterhoff N. Wie gut kennen Patienten ihre Krankheit und Behandlung? Ein Vergleich von Patientenangaben, Arztangeben und Registerdaten in der onkologischen Versorgung. Dissertation. Institut für Krebsepidemiologie e.V., Universität zu Lübeck; 2010

35 Fisher DA, Voils CI, Coffman CJ et al. Validation of a questionnaire to assess self-reported colorectal cancer screening status using face-to-face administration. Dig Dis Sci 2009; 54: 1297-1306

36 McAdams MA, Maynard JW, Baer AN et al. Reliability and sensitivity of the self-report of physician-diagnosed gout in the campaign against cancer and heart disease and the atherosclerosis risk in the community cohorts. J Rheumatol 2011; 38: 135-141
37 Cowan C, Hoskins R. Information preferences of women receiving chemotherapy for breast cancer. Eur J Cancer Care 2007; 16: 543-550

38 Raupach JC, Hiller JE. Information and support for women following the primary treatment of breast cancer. Health Expect 2002; 5: 289-301

39 Nagler RH, Gray SW, Romantan A et al. Differences in information seeking among breast, prostate, and colorectal cancer patients: results from a population-based survey. Patient Educ Couns 2010; 81 (Suppl.): S54-S62

40 Rokade A, Kapoor PK, Rao S et al. Has the internet overtaken other traditional sources of health information? Questionnaire survey of patients attending ENT outpatient clinics. Clin Otolaryngol Allied Sci 2002; 27: 526-528

41 Talosig-Garcia M, Davis SW. Information-seeking behavior of minority breast cancer patients: an exploratory study. J Health Commun 2005; 10 (Suppl. 1): 53-64

42 Satterlund MJ, McCaul KD, Sandgren AK. Information gathering over time by breast cancer patients. J Med Internet Res 2003; 5: e15

43 Mancini J, Nogues C, Adenis C et al. Patients' characteristics and rate of Internet use to obtain cancer information. J Public Health (Oxf) 2006; 28: 235-237

44 Sharpley CF, Christie DR. Patient information preferences among breast and prostate cancer patients. Australas Radiol 2007; 51: 154-158

45 van de Poll-Franse LV, van Eenbergen MC. Internet use by cancer survivors: current use and future wishes. Support Care Cancer 2008; 16: 1189-1195 